(๑) Group of authors, 2018

UDC 616-039.42

DOI - https://doi.org/10.14300/mnnc.2018.13100

ISSN - 2073-8137

\title{
POSSIBILITIES OF MOLECULAR BIOPSY IN DIFFERENTIAL DIAGNOSIS OF PULMONARY ARTERIAL HYPERTENSION: CASE DESCRIPTION AND LITERATURE REVIEW
}

Dankovtseva E. N. ${ }^{1}{ }^{2}$, Osipova N. B. ${ }^{2}$, Minushkina L. O. ${ }^{2}$, Speshilov G. I. 3, 4 , Nikitin A. G. 5 , Galyavich A. S. ${ }^{4}$, Remblevskaya K. V. ${ }^{2}$, Záteyshchikov D. A.' 1, 2, 5

${ }_{1}^{1}$ City Clinical Hospital № 51, Moscow, Russian Federation

2 Central State Medical Academy of Department of Presidential Affairs, Moscow, Russian Federation

3 Russian Academy of Sciences, A. A. Kharkevich Institute for Information Transmission Problems, Moscow, Russian Federation

4 Ridsens, Troitsk, Moscow, Russian Federation

${ }^{5}$ Federal Scientific Clinical Centre FMBA of Russia, Moscow, Russian Federation

${ }^{6}$ Kazan State Medical University, Russian Federation

\section{ВОЗМОЖНОСТИ «МОАЕКУАЯРНОЙ БИОПСИИ॥ В АИФФЕРЕНЦИААЬНОЙ АИАГНОСТИКЕ ФОРМ АЕГОЧНОЙ АРТЕРИААЬНОЙ ГИПЕРТЕНЗИИ: ОПИСАНИЕ САУЧАЯ И ОБЗОР АИТЕРАТУРЫ}

Е. Н. Аанковцева ${ }^{1,2}$, Н. Б. Осипова ${ }^{2}$, А. О. Минушкина ${ }^{2}$, Г. И. Спешилов ${ }^{3,4}$, А. Г. Никитин ${ }^{5}$, А. С. Галявич ${ }^{6}$, К. В. Ремблевская ${ }^{2}$, А. А. Затейщиков ${ }^{1,2,5}$

1 ГороАская кАиническая больница № 51 Аепартамента ЗАравоохранения г. Москвы, Москва, Российская ФеАерация

2 Центральная госуАарственная меАицинская акалемия Управления Аелами Презилента РФ, Москва, Российская Фелерация

3 Институт проблем переАачи информации им. А. А. Харкевича

Российской акаАемии наук, Москва, Российская ФеАерация

4 ООО «РиАсенс॥, Троицк, Москва, Российская ФеАерация

5 ФеАераАьный научно-КАинический центр ФМБА РФ, Москва, Российская ФеАерация

${ }^{6}$ Казанский госуАарственный МеАицинский университет, Российская ФеАерация

\footnotetext{
Precision studies of pulmonary arterial hypertension (PAH) have led to identification of the subgroup of pulmonary venoocclusive disease (PVOD). The article describes the clinical case of the hereditary form of PAH in a 53-year-old woman. Using next-generation sequencing we found biallelic mutations in the EIF2AK4 gene - c.C2965T variant in the heterozygous state resulting in the non-synonymous substitution in the position 989 of the protein (p.Arg989Trp) and the non-described variant $c .859+1 \mathrm{G}>\mathrm{A}$ in the exon 7 in the heterozygous state. Taking into consideration the genetic data, the diagnosis in this case was changed from idiopathic PAH to PVOD. So, implementation of molecular genetic methods in routine clinical examination of patients with PAH can greatly improve and speed up the diagnostic process.
}

Keywords: pulmonary arterial hypertension, pulmonary venoocclusive disease, EIF2AK4 gene mutations

Исследование патогенетических аспектов развития легочной артериальной гипертензии (ЛАГ) привело к выделению в рамках первой группы заболеваний дополнительной подгруппы - 1' - веноокклюзионная болезнь легких (ВБЛ). Генетически обусловленные формы этого заболевания наследуются по аутосомно-рецессивному типу. Представлено описание клинического случая семейной формы ЛАГ у пациентки 53 лет. При таргетном экзомном секвенировании выявлена биаллельная мутация в гене EIF2AK4: замена с.C2965T в гетерозиготном состоянии, приводящая к появлению несинонимичной замены в 989 позиции белка (p.Arg989Trp), и не описанный вариант нуклеотидной последовательности с.859+1G>A в 7 экзоне также в гетерозиготном состоянии. С учетом данных генетического исследования диагноз пациента пересмотрен с идиопатической ЛАГ на ВБЛ/ЛКГ. Таким образом, генетическое тестирование в некоторых случаях дает возможность поставить правильный диагноз и существенно ускорить диагностический процесс.

Ключевые слова: легочная артериальная гипертензия, веноокклюзионная болезнь легких, мутации гена EIF2AK4

For citation: Dankovtseva E. N., Osipova N. B., Minushkina L. O., Speshilov G. I., Nikitin A. G., Galyavich A. S., Remblevskaya K. V., Zateyshchikov D. A. POSSIBILITIES OF MOLECULAR BIOPSY IN DIFFERENTIAL DIAGNOSIS OF PULMONARY ARTERIAL HYPERTENSION: CASE DESCRIPTION AND LITERATURE REVIEW. Medical News of the North Caucasus. 2018;13(3):538-542. DOI - https://doi.org/10.14300/mnnc.2018.13100 
Для цитирования: Данковцева Е. Н., Осипова Н. Б., Минушкина Л. О., Спешилов Г. И., Никитин А. Г., Галявич А. С., Ремблевская К. В., Затейщиков Д. А. ВОЗМОЖНОСТИ «МОЛЕКУЛЯРНОЙ БИОПСИИ» В ДИФФЕРЕНЦИАЛЬНОЙ ДИАГНОСТИКЕ ФОРМ ЛЕГОЧНОЙ АРТЕРИАЛЬНОЙ ГИПЕРТЕНЗИИ: ОПИСАНИЕ СЛУЧАЯ И ОБЗОР ЛИТЕРАТУРЫ. Медицинский вестник Северного Кавказа. 2018;13(3):538-542.

DOI - https://doi.org/10.14300/mnnc.2018.13100

$\mathrm{P}$ recision studies of pulmonary arterial hypertension (PAH) have led to identification of the subgroup of pulmonary venoocclusive disease (PVOD) [1]. This subgroup also contains idiopathic and hereditary types of PVOD. The main difference of this form of PAH from other forms is its recessive heritability. The frequency of PVOD in the population is believed to be one to two cases per 1 million of the population. However, the actual prevalence of PVOD could be significantly higher because identification of this form is clinically difficult. PVOD was described in 1934 for the first time, but until 1966, its diagnosis was established only by postmortem histology [2]. PVOD is characterized by progressive fibrosis and proliferation of neointimal septal pulmonary veins and preseptal venules, and this is often accompanied by dilatation and proliferation of pulmonary capillaries. Multiple intravascular thrombi are usually found, which can be recanalized. Hypertrophy of the arteriolar wall in PVOD is similar to that of idiopathic PAH, but plexiform lesions are absent. PVOD is characterized by enlargement of the lymph nodes and dilation of lymphatic vessels. Interestingly, connective tissue disorders are sometimes inexplicably complicated with development of the venoocclusive phenotype of PVOD.

The most precise method for diagnosis of PVOD is lung biopsy, but it is contraindicated because of the high risk of the procedure. Therefore, this disease is most often detected with pulmonary transplantation or in postmortem histology. In vivo, the diagnosis of PVOD is extremely complicated.

In this report, we present the possibilities of using molecular genetic testing as a type of molecular biopsy that allows this diagnostic problem to be solved in least some patients in a relatively simple and rapid manner.

Case. A 53-year-old woman complained of exercise-induced dyspnea for at least 5 years. Her tolerance to exercise gradually decreased to functional class III. The diagnosis of PAH was established after 4 years. This time is much longer than that in other countries in which the diagnostic period is currently 2 years [3].

Sildenafil treatment $(60 \mathrm{mg})$ for 7 months did not improve the patient's condition. The six-minute walk test was $291 \mathrm{~m}$. Dyspnea by the Borg scale at the beginning of the test was 0.5 and after the test it was 4 . Pulse oximeter saturation decreased from $91 \%$ to $73 \%$ and her blood pressure reaction was normal. An echocardiography study showed considerable enlargement of the right heart chambers. The right ventricle/left ventricle basal diameter ratio was 1.3 and the left ventricular eccentricity index was 0.5 . Right ventricular hypertrophy (thickness of the free wall of $7 \mathrm{~mm}$ ) and a reduction in RL contractile function (FAC: $31 \%$, TAPSE: $14 \mathrm{~mm}$ ) was also found. The tricuspid valve regurgitation rate was $4.0 \mathrm{~m} / \mathrm{s}$. Data of invasive evaluation of pulmonary hemodynamics were as follows: pulmonary artery pressure (systolic/diastolic/mean), 46/33/39 mm Hg; right atrial pressure, 2/0/1 $\mathrm{mm} \mathrm{Hg}$; and right ventricular pressure, $30 / 11 / 18 \mathrm{~mm} \mathrm{Hg}$. Furthermore, pulmonary capillary wedge pressure was $5 \mathrm{~mm} \mathrm{Hg}$; cardiac output, was $3.9 \mathrm{l} / \mathrm{min}$, the cardiac index was $2.2 \mathrm{l} / \mathrm{min} / \mathrm{m}^{2}$, stroke volume was $61 \mathrm{ml}$, pulmonary vascular resistance was 8.7 Wood Units, and total vascular resistance was 25 Wood Units Mixed venous oxygen saturation in the left atrium was $66 \%$ and oxygen saturation in arterial blood was $92 \%$. Acute pulmonary vasodilator testing with inhaled iloprost $10 \mu \mathrm{g}$ was negative. The family history of the patient was as follows Her brother suffered from a heart condition with severe shortness of breath and died at 28 years old (he might have also had $\mathrm{PAH}$ ), and her sisters ( 58 and 46 years old) are healthy. Her father is 85 years and mother is 83 years old, and both are still alive and do not have PAH. Her first cousin on her father's side suddenly died at 35 years old, and the cause is unknown. Therefore, we can assume a family history of PAH in this patient (Figure), with a recessive type of inheritance of this disease.

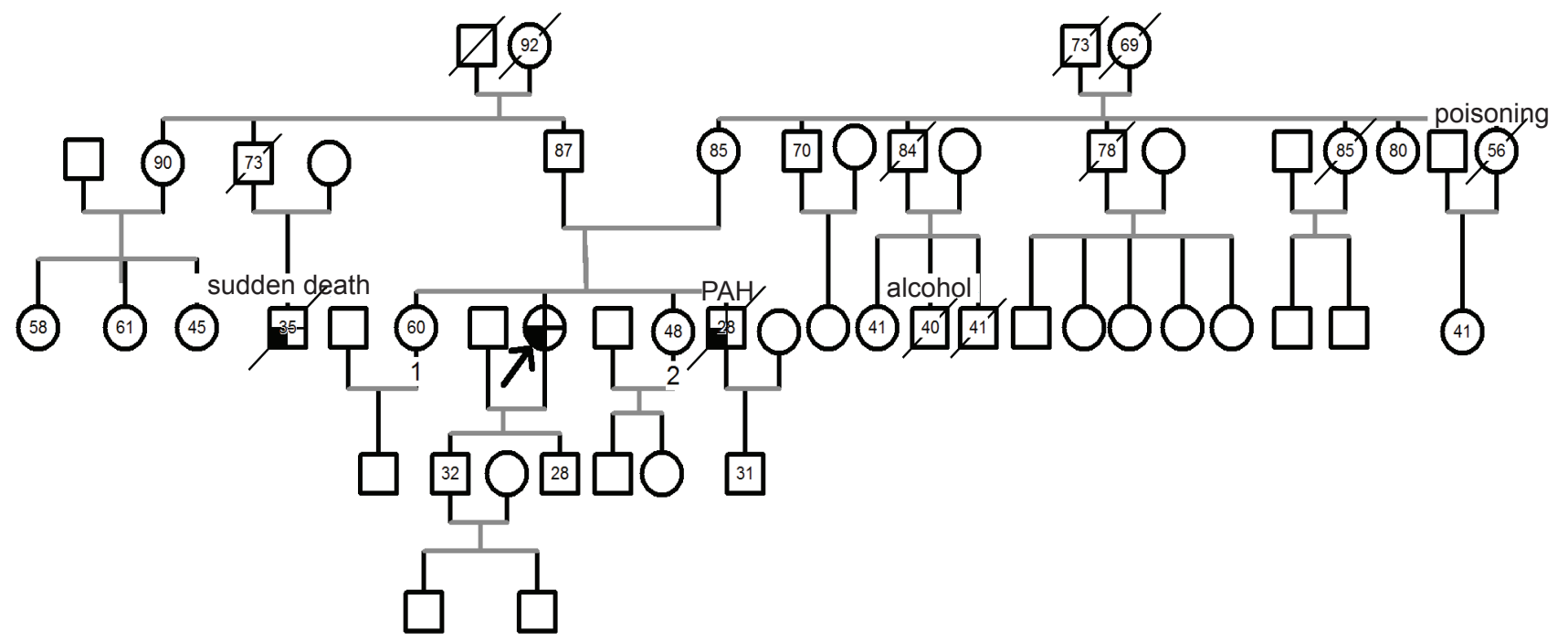

Fig. Pedigree of patient C. All cases of the disease are concentrated in one generation 
We performed targeted sequencing. DNA extraction was performed using sets for isolating genomic DNA from blood on QiaAMP spin columns (Qiagen, USA). Synthesis of DNA libraries from DNA samples for Illumina MiSeq was performed using the KAPA HyPerPlus kit (KAPA, USA). The following stages for each of the samples were performed: enzymatic DNA fragmentation, "polishing of the ends», ligation of specific sequencing adapters with unique barcodes for each of the samples, and polymerase chain reaction (PCR) from flanking primers. Enrichment with the desired gene fragments (coding regions) using a selective DNA capture technique with synthesized probes was performed with a synthetic enrichment panel of NimbleGen (Roche, USA). This process included the following steps: equimolar mixing of DNA libraries for subsequent enrichment, hybridization with synthetic probes, sorption of hybridized DNA libraries on streptavidin magnetic particles, and PCR from flanking primers. Quality control of the amplified DNA library was performed by capillary gel electrophoresis using a BioAnalyzer 2100 on HighSensitivity sets (Agilent, USA). The concentration of the amplified enriched DNA library was obtained by the fluorometric method using a Qubit DNA fluorimeter (Invitrogen, USA). Units of concentration were recalculated on the basis of capillary electrophoresis data. The enriched DNA library was then sequenced on a platform of Illumina MiSeq by pairwise readings of 2160 in accordance with the manufacturer's recommendations using a set of reagents for 300 cycles $[4,5]$. A panel of genes that are involved in development of cardiovascular disease (including involvement in the pathogenesis of $P A H$ : BMPR2, ACVRL1, BMPR1B, CAV1, EIF2AK4, ENG, FOXF1, GDF2, KCNA5, KCNK3, NOTCH3, RASA1, SMAD1, SMAD4, SMAD9, TOPBP1) was used for target next-generation sequencing. We found a variant of a nucleotide sequence, which was previously described in patients with PVOD, in exon 21 of the EIF2AK4 c.C2965T gene in the heterozygous state. This results in the appearance of a non-synonymous substitution in the 989 position of the protein (p.Arg989Trp) [6]. The frequency of the detected variant in the control sample ExAC was not higher than $0.01 \%$. Additionally, we found a variant of the nucleotide sequence c. $859+1 G>A$ in exon 7 of the EIF2AK4 gene (eukaryotic translation initiation factor 2 alphakinase 4 , a eukaryotic translational factor 2 alpha-4 kinase factor) in the heterozygous state. This leads to a violation of the splice site and has not been previously described. The frequency of the detected variant of the nucleotide sequence in the control sample of ExAC is unknown. Therefore, our patient had two mutations in the EIF2AK4 gene (biallelic mutations), which is a common finding in patients with PVOD, and confirms the recessive nature of inheritance of this disease.

Discussion. In our case, genetic testing clarified the exact cause of $\mathrm{PAH}$, which was the hereditary form of PVOD. An important feature of this form of $\mathrm{PAH}$ is the independence of sex for penetrance. In our case, PVOD was also found in the family representatives of both sexes. In Japan, PVOD is diagnosed in men more often than in women [7].

$\mathrm{PAH}$ associated with PVOD is characterized by rapid progression. A test with vasodilators has no predictive value for the effectiveness of calcium antagonist use and can cause pulmonary edema (similar to other drugs in patients with $\mathrm{PAH}$ ). This reaction is considered a pathognomonic sign of this form of $\mathrm{PAH}$, but it is not observed in all patients. Moreover, two clinically morphological phenotypes of PVOD have recently been described [3]. One of these phenotypes, which has less histological changes, is characterized by a positive response to vasodilators and a better prognosis. Prolonged ( $>15$ years) survival of patients after manifestation of symptoms of PVOD has been observed, which suggests that a different rate of progression is possible [8].

There are no specific signs to help differentiate this form from other types of $\mathrm{PAH}$. Nevertheless, certain symptoms of PVOD in some cases allow an intravital diagnosis. These symptoms include a marked decrease in the diffusing capacity of the lungs for carbon monoxide, the presence of hypoxemia at rest, and severe desaturation during physical exertion. Alveolar hemorrhage that develops because of postcapillary block leads to an increase in hemosiderin concentrations in fluid obtained from bronchoalveolar lavage [9]. Alveolar hemorrhage can also lead to an increase in hemosiderin concentrations in alveolar macrophages according to the Golde scale [10]. A chest computed tomography scan can show a combination of an increase in mediastinal lymph nodes, the symptom of «frosted glass,» and smooth thickening of interlobular septa. At the same time, specificity of this signs is low, because it is found in other types of PAH [11].

There are few data on the effectiveness of different groups of specific drugs for PVOD $[12,13]$. There is also a concern that such treatment can cause pulmonary edema. In our case, sildenafil treatment for 7 months did not result in clinical improvement, while echocardiography indicators indicated continued remodeling of the right heart.

The main genetic substrate for this form of $\mathrm{PAH}$ is pathological variants of the EIF2AK4 gene. These are associated with an earlier onset of disease compared with non-carriers and a shorter survival time to an unfavorable outcome (mean: 1 and 3 years, respectively) [14].

The outcome of mutations in the EIF2AK4 gene in family forms of PVOD was found for the first time in 2013 in 13 families who were observed in the Center for Pulmonary Hypertension in France. The diagnosis of PVOD was confirmed by biopsy data from lung transplantation in eight families and the diagnosis was based on clinical data in five families. In all of the families described, at least two affected siblings were detected from healthy parents, which confirmed the autosomal recessive type of inheritance. The age of diagnosis of PVOD ranged from 11-50 years, which is consistent with our case (symptoms appeared in 48 years). PVOD rapidly progressed in almost all cases. In all families, as well as in $20 \%$ of sporadic cases of PVOD, either homozygous carriage of recessive mutations or heterozygous carriage of combined mutations, which cause a significant decrease in protein function, was detected. The EIF2AK4 gene is present in all eukaryotes and participates in initiation of gene expression. The molecular mechanism for developing PVOD remains unknown. However, the serine/threonine protein kinase GCN2 that is encoded by this gene and involved in phosphorylation of the alpha subunit of eukaryotic translation initiation factor 2 is involved in regulating translation processes in response to stressor stimuli, providing cell resistance to inflammation, and oxidative stress. However, how the loss of function of this kinase leads to such specific changes in the microcirculation remains unclear [15].

Pathological variants in the EIF2AK4 gene are found in the majority of patients with family forms of PVOD and in $25 \%$ of sporadic cases of this disease. In patients with 
PVOD, the presence of mutations in EIF2AK4 suggests a more severe course of this disease and mortality at an earlier age [14]. Because of difficulties of intravital diagnosis and certain selection in referral centers of pulmonary hypertension, as well as a small number of observations, more favorable cases of PVOD might not be fixed.

The autosomal recessive nature of inheritance implies that, in the pedigrees of affected probands, parents can remain healthy. This type of inheritance was also observed in our patient. PVOD can develop if two recessive alleles are detected in the genotype of the pathogenic variant of the gene. This was found in a survey of 136 patients with PAH in Spain [16]. Five Roma families with $\mathrm{PAH}$ were identified, and several patients had a rapidly progressive form of this disease. In all of the families, a homozygous carrier of the $T$ allele of the variant $3344 \mathrm{C}>\mathrm{T}$ (p.P1115L) in the EIF2AK4 gene was found. Further analysis of the Spanish register of pulmonary hypertension (REHAP) showed that of 76 patients with PVOD, 19 had signs of the hereditary form [3]. Among these, 18 patients were members of eight gypsy families. Among the 76 patients, 20 homozygous carriers of the pathological variant of the EIF2AK4 gene were identified. At the time of the study, penetrance was $90 \%$ (PVOD manifested in 18 of 20 patients) [3]. Therefore, ethnic groups with traditions of endogamy can be unique providers of recessive diseases, including PVOD.

However, the family form of PVOD is usually due to carriage of biallelic mutations. At report described two brothers who were diagnosed with $\mathrm{PAH}$ and had biallelic mutations in the EIF2AK4 gene in the heterozygous state [17]. The PAH was diagnosed at the age of 20 years in one of the brothers and at 33 years in the other brother. However, the sister and parents in this family did not suffer from pulmonary hypertension. The mother and sister were heterozygous carriers of the recessive allele of the mutation 1153dupG, and the father was a heterozygous carrier of the recessive allele of the mutation T (-3766) C. Additionally, next-generation sequencing, which was performing in 10 patients with sporadic cases of PVOD, showed pathological variants of the EIF2AK4 gene in two of them. A man whose disease was diagnosed at the age of 15 years was a homozygous carrier of the 1392delT allele. Of particular interest is the case of a woman with a sporadic case of PVOD. She was diagnosed at the age of 22 years, and 10 years later, she had a left atrial pressure of $77 \mathrm{~mm}$ $\mathrm{Hg}$. This patient was a heterozygous carrier of the allele (860-1) A and mutation of 3438T (Arg1150X). The former allele leads to a violation of the splice site and is similar to the mutation found in our patient. Therefore, these data may support the pathological nature of the genetic variant found.

A family with an autosomal dominant type of inheritance of $\mathrm{PAH}$ associated with carriage of the pathologica variant of the BMPR2 gene and simultaneous carriage of a mutation in exon 38 of the EIF2AK4 gene has also been described [18]. Carrying the pathological variant of the EIF2AK4 gene proved to be a factor that contributed to penetration of PVOD caused by a mutation in the BMPR2 gene.

The use of genetic data for diagnosing PVOD without additional morphological confirmation has been described by Chinese authors [19]. These authors reported a sporadic case of $\mathrm{PAH}$ associated with carriage of the mutation c.1392delT (p.Arg465fs) of the EIF2AK4 gene. Their patient also had two mutations in the heterozygous state, which can be considered as a cause of development of pulmonary hypertension. Taking into consideration the genetic data, the diagnosis in this case was changed from idiopathic PAH to PVOD.

In conclusion, implementation of molecular genetic methods in routine clinical examination of patients with $\mathrm{PAH}$ can greatly improve and speed up the diagnostic process.

\section{Disclosures:}

The authors declare no conflict of interest.

Acknowledgment. We thank Ellen Knapp, PhD, from Edanz Group (www.edanzediting.com/ac) for editing a draft of this manuscript.

\section{References}

1. Galie N., Humbert M., Vachiery J. L., Gibbs S., Lang I. [et al.] Group ESCSD: 2015 ESC/ERS Guidelines for the diagnosis and treatment of pulmonary hypertension: The Joint Task Force for the Diagnosis and Treatment of Pulmonary Hypertension of the European Society of Cardiology (ESC) and the European Respiratory Society (ERS): Endorsed by: Association for European Paediatric and Congenital Cardiology (AEPC), International Society for Heart and Lung Transplantation (ISHLT). Eur. Heart J. 2016;37(1):67-119.

https://doi.org/10.1093/eurheartj/ehv31

2. Chaisson N. F., Dodson M. W., Elliott C. G. Pulmonary capillary hemangiomatosis and pulmonary veno-occlusive disease. Clin. Chest. Med. 2016, 37(3):523-534. https://doi.org/10.1016/j.ccm.2016.04.014

3. Navas T. P., Palomino D. J., Tenorio C. J. A., Enguita V. A. B., Rodriguez R. J. J. [et al.] Variable expressivity of a founder mutation in the EIF2AK4 gene in hereditary pulmonary veno-occlusive disease and its impact on survival. Rev. Esp. Cardiol. (Engl. Ed.). 2018;71(2):86-94. https://doi.org/10.1016/j.rec.2017.03.034

4. Chen R., Im H., Snyder M. Whole-exome enrichment with the Roche NimbleGen SeqCap EZ Exome Library SR platform. Cold Spring Harb. Protoc. 2015;(7):634641. https://doi.org/10.1101/pdb.prot084855
5. van der Werf I. M., Kooy R. F., Vandeweyer G. A robust protocol to increase NimbleGen SeqCap EZ multiplexing capacity to 96 samples. PloS One. 2015;10(4):e0123872. https://doi.org/10.1371/journal.pone.0123872

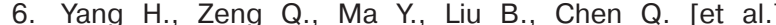
Genetic analyses in a cohort of 191 pulmonary arterial hypertension patients. Respir. Res. 2018;19(1):87. https://doi.org/10.1186/s12931-018-0789-9

7. Ogawa A., Takahashi Y., Matsubara H.: Clinical prediction score for identifying patients with pulmonary venoocclusive disease/pulmonary capillary hemangiomatosis. J. Cardiol. 2018;72(3):255-260. https://doi.org/10.1016/j.jjcc.2018.02.009

8. Matsushita K., Kanna M., Yazawa T., Shimizu S., Nitta M. [et al.] Long-term survivor with pulmonary veno-occlusive disease. Circulation. 2012;125(12):e503-e506. https://doi.org/10.1161/CIRCULATIONAHA.111.088450

9. Montani D., Lau E. M., Dorfmuller P., Girerd B., Jais X. [et al.] Pulmonary veno-occlusive disease. Eur. Respir. J. 2016;May47(5):1518-34. https://doi.org/10.1183/13993003.00026-2016

10. Lederer H., Muggli B., Speich R., Treder U., Stricker H. [et al.] Haemosiderin-laden sputum macrophages for diagnosis in pulmonary veno-occlusive disease. PloS One. 2014;9(12):e115219. https://doi.org/10.1371/journal.pone.0115219 
11. Hadinnapola C., Bleda M., Haimel M., Screaton N., Swift A. [et al.] Consortium NB-RD, Idiopathic UKNCSo, Heritable PAH, Graf S, Morrell NW: Phenotypic characterization of EIF2AK4 mutation carriers in a large cohort of patients diagnosed clinically with pulmonary arterial hypertension. Circulation. 2017;136(21):2022-2033. https://doi.org/10.1161/CIRCULATIONAHA.117.028351

12. Montani D., Lau E. M., Descatha A., Jais X., Savale L. [et al.] Occupational exposure to organic solvents: a risk factor for pulmonary veno-occlusive disease. Eur. Respir. J. 2015;46(6):1721-1731.

https://doi.org/10.1183/13993003.00814-2015

13. Chamorro F. C. I., Garces C. P., Perez M. R., Sanchez S. R. M., Ferrando S. C. [et al.] The first experience of pulmonary veno-occlusive disease treatment with macitentan and sildenafil. Rev. Esp. Cardiol. (Engl. Ed.). 2017;70(5):396-397.

https://doi.org/10.1016/j.rec.2016.07.011

14. Montani D., Girerd B., Jais X., Levy M., Amar D. [et al.] Clinical phenotypes and outcomes of heritable and sporadic pulmonary veno-occlusive disease: a populationbased study. Lancet Respir. Med. 2017 Feb;5(2):125134. https://doi.org/10.1016/S2213-2600(16)30438-6
15. Eyries M., Montani D., Girerd B., Perret C., Leroy A. [et al.] EIF2AK4 mutations cause pulmonary veno-occlusive disease, a recessive form of pulmonary hypertension. Nat. Genet. 2014;46(1):65-69. https://doi.org/10.1038/ng.2844

16. Tenorio J., Navas P., Barrios E., Fernandez L., Nevado J. [et al.] A founder EIF2AK4 mutation causes an aggressive form of pulmonary arterial hypertension in Iberian Gypsies. Clin. Genet. 2015, 88(6):579-583. https://doi.org/10.1111/cge.12549

17. Best D. H., Sumner K. L., Austin E. D., Chung W. K., Brown L. M. [et al.] EIF2AK4 mutations in pulmonary capillary hemangiomatosis. Chest. 2014;145(2):231236. https://doi.org/10.1378/chest.13-2366

18. Eichstaedt C. A., Song J., Benjamin N., Harutyunova S., Fischer C. [et al.] EIF2AK4 mutation as «second hit» in hereditary pulmonary arterial hypertension. Respir. Res. 2016; 17(1):141. https://doi.org/10.1186/s12931-016-0457-x

19. Liang L., Ma G., Chen K., Liu Y., Wu X. [et al.] EIF2AK4 mutation in pulmonary veno-occlusive disease: $A$ case report and review of the literature. Medicine (Baltimore). 2016;95(39):e5030.

https://doi.org/10.1097/MD.0000000000005030

About authors:

Dankovtseva Elena Nikolaevna, MD, PhD, Lecturer; tel.: +74991468205; e-mail: e-n-d@bk.ru

Osipova Natalya Borisovna, post-graduate student; e-mail: natalya.kudashewa@yandex.ru

Minushkina Larisa Olegovna, MD, PhD, DrSci(med), Professor; tel.: +79036738976; e-mail: minushkina@mail.ru

Speshilov Gleb Igorevich, Head of the genetic laboratory; e-mail: g.speshilov@chromaspark.com

Nikitin Alexey Georgievich, PhD, Head of the genetic laboratory; e-mail: avialn@gmail.com

Galyavich Albert Sarvarovich, MD, PhD, DrSci(med), Professor; e-mail: agalyavich@mail.ru

Remblevskaya Krestina Valerievna, post-graduate student; e-mail: nadelhalter@mail.ru

Zateyshchikov Dmitry Alexandrovich, MD, PhD, DrSci(med), Professor; tel.: +74991464151; e-mail: dz@bk.ru

(C) Group of authors, 2018

UDC 616.711.718:616.831.45-08

DOI - https://doi.org/10.14300/mnnc.2018.13101

ISSN - 2073-8137

\title{
CLINICAL CASE OF TREATMENT OF THE LEGG - CALVE - PERTHES DISEASE BY EXTENDED PARASYMPATHETIC BLOCKADE
}

\author{
Akhtyamov I. F. 1, ${ }^{2}$, Lobashov V. V. ${ }^{1,3}$, Zaidullin D. G. ${ }^{3}$, Anisimov O. G. ${ }^{1}$ \\ ${ }^{1}$ Kazan State Medical University, Russian Federation \\ 2 Republican Clinical Hospital, Kazan, Russian Federation \\ ${ }^{3}$ Clinical Hospital № 7, Kazan, Russian Federation
}

\section{КАИНИЧЕСКИЙ САУЧАЙ АЕЧЕНИЯ БОАЕЗНИ АЕГГА - КААЬВЕ - ПЕРТЕСА МЕТОАОМ ПРОААЕННОЙ ПАРАСИМПАТИЧЕСКОЙ БАОКААЫ}

\author{
И. Ф. Ахтямов ${ }^{1,2}$, В. В. Аобашов ${ }^{1,3}$, А. Г. ЗайАуммин ${ }^{3}$, О. Г. Анисимов ${ }^{1}$ \\ ${ }^{1}$ Казанский госуАарственный меАицинский университет, Российская ФеАерация \\ 2 Республиканская кАиническая больница, Казань, Российская ФеАерация \\ 3 ГороАская кАиническая больница № 7, Казань, Российская Фелерация
}

This article presents a clinical case of an effective conservative treatment of the Legg - Calve - Perthes disease in girl eight years old. The follow-up period was 7 years. The selected method of treatment was an extended parasympathetic blockade in the spine lumbar part using a Ropivacaine $0.2 \%$ solution administered daily for 12 hours. The treatment duration was 8 days.

Keywords: Legg - Calve - Perthes disease, non-operative treatment, prolonged epidural analgesia 